\title{
Phytochemical constituents of Vangueria infausta: their radical scavenging and antimicrobial activities
}

\author{
Elbert Mbukwa, Musa Chacha, and Runner R. T. Majinda* \\ Department of Chemistry, University of Botswana, Private Bag 0022, Gaborone, Botswana \\ E-mail: majindar@mopipi.ub.bw
}

Dedicated to Professor Berhanu M. Abegaz on his $60^{\text {th }}$ birthday

\begin{abstract}
A new biflavonoid, 5,7,3',5",7",4"'-hexahydroxy (4'-O-3'")-biflavone (1) and a polyketide derivative, methylcylohex-1-ene (3) [previously reported only as a synthetic compound] were isolated from aerial parts of Vangueria infausta. In addition, eight other known flavonoids viz. (-)-epicatechin, epiafzelechin, dihydrokaempferol, quercetin, luteolin (2), dihydroquercetin-3'-Oglucoside, daidzein and genistein were also isolated from this plant. Structures were identified using 1D- and 2D NMR experiments as well as ESI-MS, IR and UV spectra. The new biflavonoid 1 showed higher radical scavenging activity against 2,2-diphenyl-1-picrylhydrazyl (DPPH) reagent compared to ascorbic acid (standard) using a spectrophotometric method. Compound 1 was less sensitive to Gram-positive and Gram-negative bacterial strains and yeast (Candida mycoderma) compared to luteolin and quercetin on the Bioautographic Agar Overlay Assay.
\end{abstract}

Keywords: Vangueria infausta, flavonoids, polyketide derivative, DPPH, antibacterial, antifungal

\section{Introduction}

Vangueria infausta Burch (family Rubiaceae) is a tree 2-7 meters tall which grows well on semiarid soils and in rain forests, but has a worldwide distribution. This plant is found mostly in southern Africa but is also native to East Africa and Madagascar ${ }^{1,2}$. The fruits of $V$. infausta are eaten by both people and wild animals while different parts of this plant have been used traditionally for treatment of malaria, wounds, menstrual and uterine problems, and genital swellings among others ${ }^{3,4}$. Recent pharmacological reports have shown that extracts from leaves and roots of this plant exhibited significant antiplasmodial activity ${ }^{5,6}$. Other pharmacological activities associated with this plant are well documented ${ }^{7}$. Apart from some preliminary 
phytochemical screens, there is no reported phytochemical work identifying chemical constituents on $V$. infausta.

\section{Results and Discussion}

The plant material (leaves and stem bark extracts) were subjected to chromatographic and gel filtration techniques to give a total of ten compounds with compound $\mathbf{1}$ being reported for the first time in nature. We also report the natural occurrence of $\mathbf{3}$ as a plant secondary metabolite but had previously been reported only as a synthetic compound ${ }^{8}$. The isolated compounds were identified using spectroscopic methods.

Compound 1 was isolated from the EtOAc fraction of the leaves and was observed as a yellow spot on a TLC following a vanilin-sulphuric acid spray. The UV $\lambda_{\max }(\mathrm{MeOH})$ spectrum showed signals at 255 and $348 \mathrm{~nm}$ and the IR [(KBr) $\left.v_{\max } \mathrm{cm}^{-1}\right]$ spectrum showed absorptions at 3414 ( $\underline{\mathrm{HO}}-\mathrm{C}$ stretch), $3028\left(\underline{\mathrm{H}-\mathrm{C}=\mathrm{C} \mathrm{sp}}{ }^{2}\right.$ stretch$)$ and $1621(\underline{\mathrm{C}=\mathrm{O}}$ stretch$)$. The positive mode ESIMS spectrum of 1 exhibited a pseudomolecular ion peak at $\mathrm{m} / z 555.0[\mathrm{M}+\mathrm{H}]^{+}$corresponding to the molecular formula $\mathrm{C}_{30} \mathrm{H}_{18} \mathrm{O}_{11}$ (554.47), while a base peak ion was observed at $\mathrm{m} / z 285$ [M269] - on a negative mode ESI-MS experiment.

The ${ }^{1} \mathrm{H}$ NMR spectral data (Table 1) of $\mathbf{1}$ showed the presence of two aromatic proton spin systems similar to that of luteolin (2) ${ }^{9}$. The DEPT and HMQC experiments showed nine olefinic protonated carbon signals indicating the presence of three extra protonated olefinic carbons compared to 2. Three pairs of the twelve methine carbons were symmetrical and each pair showed proton signals integrating for two on the ${ }^{1} \mathrm{H}$ NMR experiment (Table 1) indicating that these carbons resonated on same chemical environment. The appearance of a high molecular mass $(\mathrm{m} / z 554)$ suggested existence of a flavonoid dimeric structure.

The ${ }^{1} \mathrm{H}$ and ${ }^{13} \mathrm{C}$ NMR spectral data (Table 1), DEPT, HMQC and COSY experiments showed that the first pair of protonated carbons had its protons resonating at $\delta_{\mathrm{H}} 6.21(2 \mathrm{H}, d, J=2.0 \mathrm{~Hz})$ assignable to $\mathrm{H}-8 / 8^{\prime \prime}$ protons placed at C-8/8" ( $\left.\delta_{\mathrm{C}} 99.1\right)$. The second pair was observed at $\delta_{\mathrm{H}} 6.44$ $(2 \mathrm{H}, d, J=2.0 \mathrm{~Hz})$ placed at $\mathrm{H}-6 / 6^{\prime \prime}$ and was assignable to C-6/6" ( $\left.\delta_{\mathrm{C}} 94.0\right)$ whereas the third pair of protons was observed at $\delta_{\mathrm{H}} 6.53(2 \mathrm{H}, s)$. The first two pairs display a typical characteristic of an aromatic proton spin system of a C-7/C-5 $d i$-substituted A-ring of a flavonoid molecule exhibiting a meta-coupled protons pattern ${ }^{10}$ and it was therefore suggested that compound $\mathbf{1}$ consisted of two symmetrical A-rings each displaying a meta-coupled proton spin system. This substitution pattern on A-rings was established based on HMBC and COSY experiments. The third pair of protons at $\delta_{\mathrm{H}} 6.53\left(2 \mathrm{H}, s, \delta_{\mathrm{C}} 102.9\right.$ each) were assignable to $\mathrm{H}-3$ and C-3 respectively of two luteolin 2 units ${ }^{10}$. This pair of protons at $\delta_{\mathrm{H}} 6.53$ showed HMBC correlations with C-2/2" ( $\left.\delta_{\mathrm{C}} 165.9\right), \mathrm{C}-4 / 4^{\prime \prime}\left(\delta_{\mathrm{C}} 182.9\right)$ and $\mathrm{C}-10 / 10 "\left(\delta_{\mathrm{C}} 104.3\right)$. The ${ }^{1} \mathrm{H}$ and ${ }^{13} \mathrm{C}$ NMR spectral data of 1 , furthermore, showed presence of two sets of three unsymmetrical protons on B-rings in which each ring displayed an AMX proton spin system identified by signals at $\delta_{\mathrm{H}} 7.07(1 \mathrm{H}$, br $s$, H-2', $\left.\delta_{\mathrm{C}} 109.03, \mathrm{C}-2^{\prime}\right), 6.78\left(1 \mathrm{H}, d, J=8.6 \mathrm{~Hz}, \mathrm{H}-5{ }^{\prime}, \delta_{\mathrm{C}} 114.8, \mathrm{C}-5^{\prime}\right)$, and $7.42,(1 \mathrm{H}, d d, J=7.3$, 
$2.0 \mathrm{~Hz}, \mathrm{H}-6$ ', $\left.\delta_{\mathrm{C}} 122.9, \mathrm{C}-6^{\prime}\right)$ for the first set and at $\delta_{\mathrm{H}} 7.38\left(1 \mathrm{H}\right.$, masked, H-2"', $\left.\delta_{\mathrm{C}} 113.7, \mathrm{C}-2{ }^{\prime \prime \prime}\right)$,

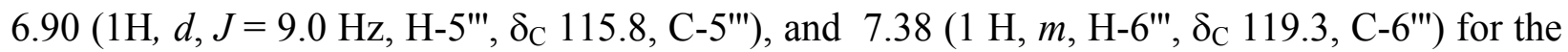
second set. These assignments were confirmed by HMBC, COSY and HMQC experiments. Further analysis of the ${ }^{13} \mathrm{C}$ NMR spectral data showed that for each set of B-rings (described above) the oxygenated carbons resonated at $\delta_{\mathrm{C}} 145.3\left(\mathrm{C}-3^{\prime}\right)$ and $150.5\left(\mathrm{C}-4^{\prime}\right)$ for the first B-ring and the second set of oxygenations were observed at $\delta_{\mathrm{C}} 149.9\left(\mathrm{C}-3^{\prime \prime \prime}\right)$ and $150.6\left(\mathrm{C}-4^{\prime \prime \prime}\right)$ on the second B-ring. The HMBC experiments confirmed these assignments.

Table 1. ${ }^{1} \mathrm{H}(300 \mathrm{MHz})$ and ${ }^{13} \mathrm{C}(75.4 \mathrm{MHz}) \mathrm{NMR}$ data for compound 1 in methanol- $\mathrm{d}_{4}$

\begin{tabular}{|c|c|c|c|c|}
\hline \multirow{2}{*}{$\begin{array}{l}\text { Position } \\
\left(\mathrm{M}_{1} / \mathrm{M}_{2}\right)\end{array}$} & \multicolumn{4}{|c|}{ Monomers* } \\
\hline & $\delta_{\mathrm{H}}$ & Multiplicity & $\mathrm{M}_{1}\left(\delta_{\mathrm{C}}\right)$ & $\mathrm{M}_{2}\left(\delta_{\mathrm{C}}\right)$ \\
\hline $2 / 2^{\prime \prime}$ & & & 165.3 & 165.3 \\
\hline $3 / 3^{\prime \prime}$ & 6.53 & $2 \mathrm{H}, s$ & 102.9 & 102.9 \\
\hline $4 / 4^{\prime \prime}$ & & & 182.9 & 182.9 \\
\hline $6 / 6^{\prime \prime}$ & 6.21 & $2 \mathrm{H}, d,(2.0 \mathrm{~Hz})$ & 99.1 & 99.1 \\
\hline $7 / 7 "$ & & & 164.9 & 164.9 \\
\hline $8 / 8^{\prime \prime}$ & 6.44 & $2 \mathrm{H}, d,(2.0 \mathrm{~Hz})$ & 94.0 & 94.0 \\
\hline 9/9" & & & 158.4 & 158.4 \\
\hline 10/10" & & & 104.3 & 104.3 \\
\hline $1^{\prime} / 1^{\prime \prime \prime}$ & & & 122.7 & 122.7 \\
\hline $2^{\prime}$ & 7.07 & $1 \mathrm{H}, b r s$ & 109.3 & \\
\hline $2 " '$ & 7.38 & $1 \mathrm{H}$, masked & & 113.7 \\
\hline $3^{\prime} / 3^{\prime \prime \prime}$ & & & 145.3 & 149.9 \\
\hline $4^{\prime} / 4^{\prime \prime \prime}$ & & & 150.5 & 150.6 \\
\hline $5^{\prime}$ & 6.78 & $1 \mathrm{H}, d,(8.6 \mathrm{~Hz})$ & 114.8 & \\
\hline $5 "$ & 6.90 & $1 \mathrm{H}, d,(9.0 \mathrm{~Hz})$ & & 115.8 \\
\hline $6^{\prime}$ & 7.42 & $1 \mathrm{H}, d d,(7.3,2.0 \mathrm{~Hz})$ & 122.9 & \\
\hline 6"' & 7.38 & $1 \mathrm{H}, m$ & & 119.3 \\
\hline 5/5"-OH & & & 162.2 & 162.2 \\
\hline
\end{tabular}

Assignments were confirmed by HMBC, HMQC, DEPT, NOE and COSY experiments.

$J$ values are in parentheses. *Assignments in the main row can be used interchangeably between monomers

The UV spectrum of $\mathbf{1}$ did not show any change on band I after addition of $\mathrm{HCl}$ compared to that observed in $\mathrm{AlCl}_{3}$ showing there were no complexes formed at the $\mathrm{C}-3^{\prime} / \mathrm{C}-4^{\prime}$ and $\mathrm{C}-3^{\prime \prime \prime} / \mathrm{C}-4^{\prime \prime \prime}$ 
positions suggesting absence of free ortho-dihydroxyl groups on B-rings compared to the UV spectrum of $2^{11}$. Furthermore, the unchanged UV spectrum on band I (cinnamoyl moiety) when $\mathrm{NaOAc} / \mathrm{H}_{3} \mathrm{BO}_{3}$ was added ${ }^{9}$ confirmed this suggestion. Again, the observed bathochromic shift on bands II (benzenoid moiety) of $\mathbf{1}$ and $\mathbf{2}$ after addition of $\mathrm{NaOAc}$ indicated presence of free $\mathrm{C}$ 7/7")-hydroxyl groups in 1 [and C-7 in luteolin (2)]. The IR absorption band observed at 3414 $\mathrm{cm}^{-1}$ represented $\mathrm{OH}$ stretch which because of lower wavenumbers are be due to chelated hydroxyl groups at C-5/5" in 1 . The UV and NMR experiments suggested that the two B-rings of 1 are involved in the interflavone linkage system. The observed ESI-MS fragment ion at $m / z 285$ [M-269] confirms fragmentation pattern at the ether linkage of $\mathbf{1}$ and thus a-C-O-C- linkage was established. In order to locate which carbons on rings B are involved in the linkage the number and positions of free hydroxyl groups were identified by methylation of 1 using diazomethane to yield compound 1a which showed presence of six methoxy groups at C-5, C-7, C-3', C-5", C-7", C-4"'. The symmetrical pairs of methoxy groups were observed at C-5/C-5" and C-7/C-7" carbon pairs on A-rings and these assignments were confirmed by HMBC experiment. In a NOE experiment (for 1a), when $\mathrm{H}-2^{\prime}$ proton signal was irradiated only the methoxy group signal attached at carbon C-3' was enhanced while irradiation of $\mathrm{H}-5^{\prime \prime}$ signal enhanced the methoxy group attached to carbon C-4"'. It was thus established and found that the interflavone -C-O-Cether linkage involved B-rings through C-4'-O-C-3'" connection. Compound 1 was thus identified as 5,7,3',5",7",4'"-hexahydroxy-(4'-O-3"')-biflavone or apigenin-3'-O-4'"-luteolin and there is no report, to the best of our knowledge, of this compound from the genus Vangueria or in nature.

Compound 3 was isolated from the chloroform fraction of the leaves as a colorless liquid. A positive ESI-MS pseudomolecular ion peak was recorded at $m / z 97[\mathrm{M}+\mathrm{H}]^{+}$corresponding to the molecular formula $\mathrm{C}_{7} \mathrm{H}_{12}$. The available data (IR, ${ }^{1} \mathrm{H}$ NMR, ${ }^{13} \mathrm{C}$ NMR, HMQC and HMBC) enabled easy identification of compound $\mathbf{3}$ as methylcyclohex-1-ene. There is no report of this compound as a natural product but it has been reported as a synthetic compound ${ }^{8}$. The occurrence of compound $\mathbf{3}$ from the genus Vangueria and nature is reported here for the first time. Compound $\mathbf{3}$ is probably biosynthesized from a tetraketide which upon cyclisation and subsequent reduction gave the metabolite. The rest of the isolated compounds were all known however, this is the first report on occurrence of these compounds in the genus Vangueria. Structural identifications of these compounds were further confirmed by comparing with literature values.

The stable radical scavenging reagent, 2,2-diphenyl-1-picrylhydrazyl (DPPH) was employed $^{12}$ to evaluate the ability of the crude extracts and the isolated compounds in exhibiting radical scavenging activity by determining the $\mathrm{EC}_{50}$ value. The $\mathrm{EC}_{50}$ value defines the substrates' concentration that causes $50 \%$ loss of DPPH absorbance at $517 \mathrm{~nm}$ on a UV-VIS spectrophotometer ${ }^{13}$. Compound $\mathbf{1}$ showed the highest antiradical scavenging activity $\left[\mathrm{EC}_{50 \mathrm{~s}}\right.$ of $11.0 \mu \mathrm{g} / \mathrm{ml}(19.9 \mu \mathrm{M})$ and $0.7 \mu \mathrm{g} / \mathrm{ml}(1.2 \mu \mathrm{M})$ after half and 24 hours, respectively] (Table 2). The $\mathrm{EC}_{50}$ values of all test compounds are as shown (Table 2). Radical scavenging activity for the active compounds was found to be faster in the first three hours of reaction and only slight 
differences in $\mathrm{EC}_{50}$ values were observed thereafter. This shows that the steady state conditions are attained after three hours. The structure- activity relationship studies have shown that among other factors, the more the hydroxyl groups in a molecule the higher the antioxidant activity of that molecule $e^{14,15}$.

Table 2. Radical scavenging activity of crude extracts and pure compounds from $V$. infausta

\begin{tabular}{|c|c|c|c|c|c|c|c|c|c|c|}
\hline \multirow[t]{3}{*}{ Compound/extract } & \multicolumn{10}{|c|}{ Quantitative estimation of $\mathrm{EC}_{50}$ values at different times } \\
\hline & \multicolumn{2}{|c|}{30 mins } & \multicolumn{2}{|c|}{$3 \mathrm{Hrs}$} & \multicolumn{2}{|c|}{$6 \mathrm{Hrs}$} & \multicolumn{2}{|c|}{$24 \mathrm{Hrs}$} & \multicolumn{2}{|c|}{$48 \mathrm{Hrs}$} \\
\hline & $\mu \mathrm{g} / \mathrm{ml}$ & $\mu \mathrm{M}$ & $\mu \mathrm{g} / \mathrm{ml}$ & $\mu \mathrm{M}$ & $\mu \mathrm{g} / \mathrm{ml}$ & $\mu \mathrm{M}$ & $\mu \mathrm{g} / \mathrm{ml}$ & $\mu \mathrm{M}$ & $\mu \mathrm{g} / \mathrm{ml}$ & $\mu \mathrm{M}$ \\
\hline Ascorbic acid & 48.0 & 272.7 & 18.0 & 102.3 & 10.4 & 59.1 & 8.4 & 47.7 & 8.2 & 46.6 \\
\hline stem bark $(\mathrm{MeOH})$ & 187.0 & - & 123.0 & - & 118.0 & - & 110.0 & - & 108.0 & - \\
\hline Leaves (EtOAc) & 102.0 & & 87.0 & - & 39.4 & - & 32.1 & - & 31.8 & - \\
\hline 1 & 11.0 & 19.9 & 4.5 & 8.1 & 0.9 & 1.6 & 0.7 & 1.2 & 0.7 & 1.2 \\
\hline 2 & 24.0 & 83.8 & 9.0 & 31.4 & 4.5 & 15.7 & 3.5 & 12.2 & 3.5 & 12.5 \\
\hline 3 & NT & NT & NT & NT & NT & NT & NT & NT & NT & NT \\
\hline (-)-epicatechin & 92.5 & 318.7 & 35.0 & 120.6 & 21.3 & 73.4 & 15.7 & 54.1 & 15.5 & 53.4 \\
\hline Epiafzelechin & $>200$ & - & $>200$ & - & $>200$ & - & 153.0 & 560.0 & 146.0 & 534.6 \\
\hline Daidzein & $>200$ & - & $>200$ & - & $>200$ & - & $>200$ & - & $>200$ & - \\
\hline Genistein & $>200$ & - & $>200$ & - & $>200$ & - & 153.0 & 566.0 & 146.0 & 574.4 \\
\hline Dihydrokaempferol & $>200$ & - & 156.2 & 541.6 & 123.0 & 426.9 & 118.5 & 411.0 & 118.5 & 409.6 \\
\hline Quercetin & 35.0 & 115.8 & 13.0 & 43.0 & 5.5 & 18.2 & 4.7 & 15.5 & 4.6 & 15.2 \\
\hline $\begin{array}{l}\text { Dihydroquercetin-3'- } \\
\text { O-glucoside }\end{array}$ & 72.0 & 154.4 & 31.0 & 66.5 & 11.5 & 24.6 & 8.2 & 17.6 & 8.2 & 17.6 \\
\hline
\end{tabular}

Key: NT $=$ Not tested

The antimicrobial activity of compounds was studied using the method by Rahalison et al. ${ }^{16}$. The exact procedure is as described by Chacha et al. ${ }^{17}$. Chloramphenicol and miconazole (Sigma) were employed as standard antibacterial and antifungal, respectively. (-)-Epicatechin and epiafzelechin were found active against E. coli at minimum loading of 50.0 and $100.0 \mu \mathrm{g}$, respectively. Quercetin and luteolin (2) were active at a loading of $5.0 \mu \mathrm{g}$ and the biflavone $\mathbf{1}$ was only weakly active at this loading. The isoflavonoid, genistein was active at a minimum loading of $100.0 \mu \mathrm{g}$ whereas daidzein was inactive against E. coli at this loading. The C-5 hydroxylation on genistein seemed to be important for this activity. Quercetin and luteolin (2) were active at a loading of $5.0 \mu \mathrm{g}$ against $B$. subtilis while the former was active at loading of 0.1 $\mu \mathrm{g}$ against $S$. aureus. The biflavonoid 1 was less active $(10.0 \mu \mathrm{g})$ against $S$. aureus compared to 2, one of its monomeric units. Quercetin and luteolin (2) were active at a loading of $0.1 \mu \mathrm{g}$ against $C$. mycoderma whereas compound 1 was only active at a minimum loading of $5.0 \mu \mathrm{g}$. All compounds and crude extracts were less active against all microorganisms compared to the standards used (Table 3). 


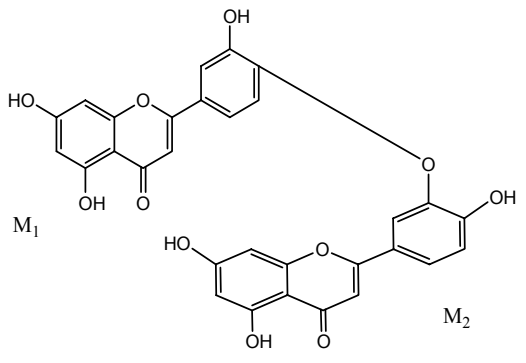

1

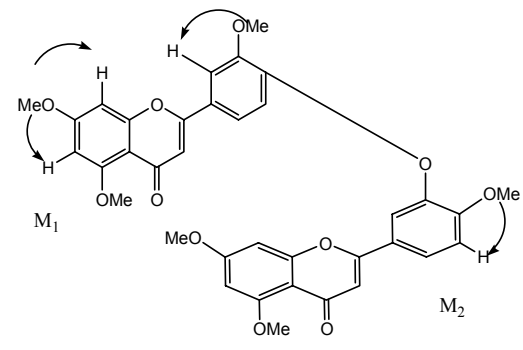

1a NOE relations observed<smiles>O=c1cc(-c2ccc(O)c(O)c2)oc2cc(O)cc(O)c12</smiles>

2<smiles>CC1=CCCCC1</smiles>

3

Table 3. Antimicrobial activities of stem bark and leaf extracts and pure compounds

\begin{tabular}{|c|c|c|c|c|}
\hline \multirow[t]{2}{*}{ Compound/extract } & \multicolumn{4}{|c|}{ Minimum inhibitory amount $(\mu \mathrm{g})$ shown numerically } \\
\hline & B. subtilis & E. coli & S. aureus & C. mycoderma \\
\hline Stem bark (Crude $\mathrm{MeOH})$ & 50.0 & 100.0 & 10.0 & 5.0 \\
\hline Leaves (Crude EtOAc) & 50.0 & 50.0 & 10.0 & 5.0 \\
\hline 1 & NT & $5.0 \mathrm{~W}$ & 10.0 & 5.0 \\
\hline 2 & 5.0 & 5.0 & 5.0 & 0.1 \\
\hline 3 & NT & NT & NT & NT \\
\hline Dihydrokaempferol & $10.0 \mathrm{~W}$ & $5.0 \mathrm{~W}$ & $\mathrm{I}^{* *}$ & $\mathrm{I}^{* *}$ \\
\hline Quercetin & 5.0 & 5.0 & 0.1 & 0.1 \\
\hline $\begin{array}{l}\text { Dihydroquercetin-3'-O- } \\
\text { glucoside }\end{array}$ & $50.0 \mathrm{~W}$ & 50.0 & $I^{* *}$ & 50.0 \\
\hline Daidzein & 50.0 & $\mathrm{I} * *$ & 5.0 & 10.0 \\
\hline Genistein & 10.0 & 5.0 & 50.0 & $\mathrm{I}^{*}$ \\
\hline (-)-epicatechin & 10.0 & 50.0 & 10.0 & 10.0 \\
\hline Epiafzelechin & $5.0 \mathrm{~W}$ & 100.0 & 10.0 & 50.0 \\
\hline Miconazole (std) & & & & 0.0005 \\
\hline Chloramphenicol (std) & & & 0.001 & \\
\hline
\end{tabular}

KEY: $\mathrm{I}^{* *}=$ Inactive at $100.0 \mu \mathrm{g}, \mathrm{I}^{*}=$ Inactive at $50.0 \mu \mathrm{g}, \mathrm{W}=\mathrm{Weak}, \mathrm{NT}=$ Not Tested. 


\section{Experimental Section}

General procedures. UV-VIS spectra: Shimadzu UV-2101PC UV-VIS Scanning Spectrophotometer. NMR experiments: 1D $\left[{ }^{1} \mathrm{H}(300\right.$ and/or $600 \mathrm{MHz}),{ }^{13} \mathrm{C}(75.4$ and/or 150.9 $\mathrm{MHz}), \mathrm{DEPT}]$ and 2D [COSY, HMBC, HMQC] were acquired on Bruker Avance DPX 300 and/or DRX 600 spectrometers, signals were referenced to deutereted solvents. Melting points: Stuart Scientific (SMP1) melting point instrument. The infrared (IR) spectra were recorded on Perkin Elmer 2000 FT-IR spectrophotometer and mass spectra were acquired from Finnigan LCQ $^{\text {DECA }}$ instrument. Specific rotations $[\alpha]_{D}$ were determined using the Autopol IV (Rudolph Research Analytical) Automatic Polarimeter.

Materials and extraction. Parts of Vangueria infausta were collected in March 2002 from Mapoka village, North East District in Botswana. A voucher specimen number RRT.2/2002 was deposited at the Herbarium, Department of Biological Sciences, University of Botswana.

The powdered leaves (461 g) were soaked in $\mathrm{MeOH} / \mathrm{CHCl}_{3}(1: 1)$ and then in $\mathrm{MeOH}(100 \%)$. The solvent was removed under reduced pressure and the dried extracts were combined to give $22.5 \mathrm{~g}$ of crude green tar. Part of this residue $(22.0 \mathrm{~g})$ was suspended in $150 \mathrm{ml}$ of water and successively partitioned between $\mathrm{CHCl}_{3}$ and EtOAc to give $4.2 \mathrm{~g}$ and $6.8 \mathrm{~g}$ fractions, respectively. The powdered stem bark $(650 \mathrm{~g})$ was treated similarly to yield $60 \mathrm{~g}$ of crude extract. This extract was subjected to VLC and eluted with hexane, $\mathrm{CHCl}_{3}$ and $\mathrm{MeOH}$ to give 0.7 $\mathrm{g}, 3.8 \mathrm{~g}$ and $17.6 \mathrm{~g}$ fractions, respectively.

Isolation of compounds. Part of the EtOAc fraction $(6.0 \mathrm{~g})$ was adsorbed on silica gel $(6.0 \mathrm{~g})$ and subjected to chromatographic column and eluted with $\mathrm{CHCl}_{3} 100 \%$ [fr. 1-4]; $\mathrm{CHCl}_{3} / \mathrm{EtOAc}$ (30:70) [fr. 5-53]; EtOAc (100 \%) [fr. 54-69]; EtOAc/MeOH (60: 40) [fr. 70-83], each collected fraction was $250 \mathrm{ml}$ in size. The above fractions were combined as A: 19/34, B: 37/42, C: 43/44, D: $59 / 69$ and E: $73 / 77$ based on similarities of TLC profiles. The combined fraction D (140 mg) was concentrated and applied on Sephadex LH-20 column and eluted with $\mathrm{CHCl}_{3} / \mathrm{MeOH}(1: 1)$ giving 54 sub-fractions ( $20 \mathrm{ml}$ each). Sub-fractions 36/43 were combined to give $\mathbf{1}$ (16.2 $\mathrm{mg}$ ). Preparative TLC on combined fraction A $(30.0 \mathrm{mg})$ using $\mathrm{MeOH} / \mathrm{CHCl}_{3}$ (7:93) [x6 development] yielded (-)-epicatechin $(17.8 \mathrm{mg})^{18}$. Gel filtration [Sephadex LH-20, $\mathrm{MeOH} / \mathrm{CHCl}_{3}$ (1:1)] on combined fraction B gave 22 sub-fractions ( $20 \mathrm{ml}$ each). Sub-fractions 14/18 yielded $6.2 \mathrm{mg}$ of quercetin ${ }^{10}$. Combined fraction C yielded luteolin (2) $(10.8 \mathrm{mg})$ on concentration. More luteolin $(70.6 \mathrm{mg}$ ) was obtained from combined fraction E. The chloroform fraction of the leaves yielded luteolin as a major product and $\mathbf{3}(6 \mathrm{mg})$.

The methanolic fraction of the stem bark (17 g) was subjected to column chromatography using gradient solvent system (hexane $\rightarrow$ EtOAc $\rightarrow \mathrm{MeOH}$ ) giving 115 fractions $(250 \mathrm{ml}$ each). Subfractions 84/97 [EtOAc/MeOH (60:40)] were combined to give $780.8 \mathrm{mg}$ of residue. This residue was dissolved in $\mathrm{MeOH}$ applied to Sephadex LH-20 column and eluted with $\mathrm{CHCl}_{3} / \mathrm{MeOH}$ (1:1) giving twenty sub-fractions $(100 \mathrm{ml}$ each). Sub-subfraction 8 gave 
dihydroquercetin-3'-O-glucoside (12.4 mg $)^{19}$. Sub-fractions $10 / 11$ were combined and concentrated to give a mixture of two compounds $(40.1 \mathrm{mg})$. Repeated gel filtration of this mixture yielded epiafzelechin $(7.7 \mathrm{mg})^{20}$ and dihydrokaempferol $(10.1 \mathrm{mg})^{21}$. PTLC $\left(\mathrm{CHCl}_{3} / \mathrm{MeOH}, 85: 15\right)$ of sub-fraction $12 / 16(140 \mathrm{mg})$ gave 5 bands on development. Band one gave traces of dihydrokaempferol whereas band two showed traces of quercetin. Band three gave a pale yellow material $(13.9 \mathrm{mg})$ identified as genistein and band four gave daidzein $(9.3 \mathrm{mg})^{22}$. Band five gave trace amounts of a compound which could not be identified.

5,7,3',5",7',4"'-Hexahydroxy (4'-O-3'"')-biflavone (1). Yellow solid, mp 333-336 ${ }^{\circ} \mathrm{C}$; UV $\lambda_{\max }(\mathrm{MeOH}) \mathrm{nm}:$ 255, 266, 341, 348, +NaOMe: 263, 330, 413, $+\mathrm{AlCl}_{3}$ 257, 344, 349, $+\mathrm{AlCl}_{3} / \mathrm{HCl}: 255,265,349,+\mathrm{NaOAc}: 270,339,368,+\mathrm{NaOAc} / \mathrm{H}_{3} \mathrm{BO}_{3}$ : 259, 369; IR (KBr) $v_{\max }$ $\left(\mathrm{cm}^{-1}\right): 3414$ ( $\underline{\mathrm{HO}}-\mathrm{C}$ stretch$), 3028(\underline{\mathrm{HC}}=\mathrm{C}$ stretch$), 1621(\mathrm{C}=\mathrm{O}$ stretch$) ;{ }^{1} \mathrm{H}$ and ${ }^{13} \mathrm{C}$ NMR data (see Table 1); positive mode ESI-MS m/z: $555[\mathrm{M}+\mathrm{H}]^{+}(2)\left[\mathrm{C}_{30} \mathrm{H}_{18} \mathrm{O}_{11}, 554\right], 258.7$ [M-296] ${ }^{+}$ (97), negative mode ESI-MS m/z: 285 [M-269] ${ }^{-}$(100).

5,7, 3',4'-Tetrahydroxyflavone (2). Yellow solid, mp 329-331 ${ }^{\circ} \mathrm{C}$ (lit. 327-231 ${ }^{\circ} \mathrm{C}$ ); UV $\lambda_{\max }$ $(\mathrm{MeOH}) \mathrm{nm}: 256,267,349,+\mathrm{NaOMe}: 265,329,405,+\mathrm{AlCl}_{3}: 272,333,426,+\mathrm{AlCl}_{3} / \mathrm{HCl}: 269$, 356, 384, +NaOAc: $271,325,385,+\mathrm{NaOAc} / \mathrm{H}_{3} \mathrm{BO}_{3} 275,399$; IR (KBr) $v_{\max }\left(\mathrm{cm}^{-1}\right)$ : 3468 ( $\underline{\mathrm{HO}}-$ $\mathrm{C}$ stretch), $3144(\underline{\mathrm{HC}}=\mathrm{C}$ stretch$), 1617(\underline{\mathrm{C}=\mathrm{O}}$ stretch $) ;{ }^{13} \mathrm{C}$ NMR identical with reported data ${ }^{10}$; negative mode ESI-MS m/z: 285.3 [M - H] $]^{-}(100)\left[\mathrm{C}_{15} \mathrm{H}_{10} \mathrm{O}_{6}, 286\right], 133.1[\mathrm{M}-\mathrm{H}-152]^{-}$(2).

Methylcyclohex-1-ene (3). Colorless liquid bp 109-111 ${ }^{\circ} \mathrm{C}$; IR (film) $v_{\max }\left(\mathrm{cm}^{-1}\right)$ : $3012(\underline{\mathrm{HC}}=\mathrm{C}$ stretch), 2940 ( $\underline{\mathrm{HC}}-\mathrm{C} \mathrm{sp}{ }^{3}$ stretch), $1654\left(\mathrm{C}=\mathrm{C}\right.$ stretch); ${ }^{1} \mathrm{H}(\delta \mathrm{ppm}): 1.673 \mathrm{H}, s ; 1.294 \mathrm{H}, m ; 2.04$ $4 \mathrm{H}$, br $s$ and $5.131 \mathrm{H}$, br $s$. and ${ }^{13} \mathrm{C}$ NMR $(\delta \mathrm{ppm}): 23.1,23.8,26.8,30.1,32.5,125.4$ and 135.6; ESI-MS (positive mode) $m / z: 97[\mathrm{M}+\mathrm{H}]^{+}(15)\left[\mathrm{C}_{7} \mathrm{H}_{12}, 96\right], 81[\mathrm{M}-15]^{+}(55)$.

Radical scavenging activity. The $\mathrm{EC}_{50}$ values for crude stem bark (methanolic) and leaf (EtOAc) extracts, ascorbic acid (standard) and pure compounds were determined by adopting same procedure as described by Juma and Majinda ${ }^{23}$.

Antimicrobial activity. The method by Rahalison et al. ${ }^{16}$ was followed and specific details are described by Chacha et al. ${ }^{17}$.

\section{Acknowledgements}

E $\mathrm{M}$ and $\mathrm{M} C$ thanks DAAD-NAPRECA program for scholarship awards. $\mathrm{E} M$ also acknowledges the University of Botswana for a teaching assistantship. MC thanks the University of Dar Es Salaam for a study leave and RRTM acknowledges IFS research fund (Grant No.F/2698/2). 


\section{References}

1. Watt, J. M.; Breyer-Brandwijk, M. G. Medicinal and Poisonous Plants of Southern and Eastern Africa. $2^{\text {nd }}$ Edn.; Livingstone Ltd: Edinbugh, 1962.

2. Verdcourt, B.; Bridson, D. M. Flora of Tropical East Africa. Rubiceae Part 3, 1991.

3. Chhabra, S. C.; Mahunnah, R. L. A.; Mshiu, E. N. J Ethnopharmacol.1984, 11, 157.

4. Chhabra, S. C.; Mahunnah, R. L. A.; Mshiu, E. N. J Ethnopharmacol. 1991, 33,143.

5. Nundkumar, N.; Ojewole, J. A. Method Find. Exp. Clin. 2002, 24, 397.

6. Abosi, A. O. PhD Thesis, University of Botswana, 2005.

7. NAPRALERT Data Base, 2004.

8. Nugent, W. A.; Feldman, J.; Calabrese, J. C. J. Am. Chem. Soc. 1995, 117, 8992.

9. Markham, K. R. Techniques of Flavonoid Identification. Academic Press: London, 1982.

10. Agrawal, P. K. In Carbon-13 NMR of Flavonoids ; Agrawal, P. K. Ed.; Elsevier: New York, 1989 p 507.

11. Tomczyk, M.; Gudej, J.; Sochack, M. Z. Naturforsch C 2002, 57, 440.

12. Kumarasamy, Y.;. Ferguson, M. E.; Nahar L.;. Sarker, S. D. Pharm. Biol. 2002, 40, 307.

13. Takao, T.; Kitatani, F.; Watanabe, N.; Yagi, A.; Sakata, K. Biosci. Biotech. Biochem. 1994, $58,1780$.

14. Blokhina, O.; Virolainen, E.; Fagerstedt, V. K. Ann. Bot. 2003, 9, 174.

15. Dugas, A. J.; Castaneda-Acosta, J.; Bonin, G.; Prince, L. K.; Fischer, H. N.; Winston, W. G. J. Nat.Prod. 2000, 63, 327.

16. Rahalison, L.; Hamburger, M. J.; Hostettmann, K.; Monod, M.; Frenk, E. Phytochem. Analysis 1991, 2, 199.

17. Chacha, M.; Bojase-Moleta, G.; Majinda, R. R. T. Phytochemistry 2005, 66, 99.

18. Agrawal, P. K.; Bansal, M. C.; Porter, L. J.; Foo, L. Y. In Carbon-13 NMR of Flavonoids; Agrawal, P. K. Ed.; Elsevier: New York, 1989, pp 444, 446.

19. Agrawal, P. K.; Agarwal, S. K; Rastogi, R. P. Phytochemistry 1980, 19, 1260.

20. Hwang, B. J.; Kim, H. S.; Lee, J. H.; Hong, Y. S.; Ro, J. S.; Lee, K. S.; Lee, J. J. J. Nat. Prod. 2001, 64, 82 .

21. Wellman, F.; Lucacin, R.; Moriguchi, T.; Britsch, L.; Schiltz, E.; Matern, U. Eur. J. Biochem. 2002, 269, 4134.

22. Kosslake, R. M.; Bookland, R.; Barkei, J.; Paaren, H. E.; Appelbaum, E. R. Proc. Natl. Acad. Sci. 1987, 84, 7428.

23. Juma, B. F.; Majinda, R. R. T. Phytochemistry 2004, 65, 1397. 